\title{
Adherence to an overweight and obesity treatment: How to motivate a patient?
}

Objective: To explore anthropometric changes in normal-weight, overweight and obese subjects who did not dropout or failed a weight loss program over the 16 treatment weeks to improve patient's motivation and treatment adherence. Methods: A clinical intervention study was conducted among 271 (including 100 dropouts and/or failures) obese and overweight patients who consulted a nutrition clinic in Barranquilla (Colombia) for the purpose of nutritional assessment. They were subject to a personalized weekly follow-up consultation over the course of 16 weeks in which initial and the final Body Mass Index (BMl, $\left.\mathrm{kg} / \mathrm{m}^{2}\right)$, photographs, food consumption patterns, percentage weight loss, waist and hip circumference were registered and grouped according to BMI, measuring treatment response. Data's nonparametric statistical comparison was made. Results: In 62 patients from $\mathrm{BMl}<25$ group, there is a weight loss of $2.6 \%(3.1 \mathrm{SD}), 5.5 \%(3.3 \mathrm{SD})$ in waist circumference and 3.0\%(2.5SD) in hip circumference. In 67 patients from $25 \geq \mathrm{BMl}<30$ group, there is a weight loss of $3.8 \%(4.1 \mathrm{SD}), 5.7 \%(4.5 \mathrm{SD})$ in waist circumference loss and $3.7 \%(3.0 S D)$ in hip circumference loss. In 42 patients from $\mathrm{BMI}>30$ group, there is a weight loss of $4.8 \%(3.7 S D), 7.0 \%(3.6 S D)$ in waist circumference loss and $3.9 \%(2.4 S D)$ in hip circumference loss. Monitoring is done every 4 weeks by the Friedman test, with significant differences between the three groups $(p<0.001)$. Patients do not dropout treatment because they start to see physical results in waist decrease. Comparing initial waist/hip circumference ratio and waist/height ratio regarding to final values a clear decrease in the three $\mathrm{BMI}$ groups was observed $(p<0.001)$. Conclusion: After three weeks of continuous treatment patients improved all overweight and obesity parameters indicators; there were not statistical significant differences in hip circumference (HC) and waist loss (WC) (\%) among the three BMI groups (normal-weight, overweight, and obesity). In contrast, there were statistical significant differences in weight loss (\%) and waist-to-hip ratio. Based on anthropometric outcomes and patient perception of their body image it can be concluded that the waist PeerJ reviewing PDF | (v2014:05:2137:1:3:NEW 28 Jun 2014) 
circumference loss is the parameter that adhere obese patients to the weight loss program. 
2 Corresponding Author:

3

4

5

6

7 Email:

8 Contributing Authors:

9

10

11 Email:

12

13

14

15 Email:
Isaac Kuzmar, MD

Faculty of Health Sciences

University of Alicante

Carretera de San Vicente del Raspeig, s/n

03690, Alicante, Spain

isaackuzmar@yahoo.es

Mercedes Rizo, PhD

Faculty of Health Sciences

University of Alicante, Spain

mercedes.rizo@ua.es

Ernesto Cortés-Castell, PhD

School of Medicine

Miguel Hernandez University, Spain

ernestocort@gmail.com 
17 Overweight (body mass index, BMI $25-30 \mathrm{~kg} / \mathrm{m}^{2}$ ) and obesity (BMI $\geq 30 \mathrm{~kg} / \mathrm{m}^{2}$ ) are 18 preventable diseases defined as abnormal or excessive fat accumulation that 19 sometimes favours the onset of disease ${ }^{1}$.

20 Over the years, the obesity prevalence significantly increases ${ }^{2}$ thanks to a decrease in 21 caloric expenditure and increased energy consumption, resulting from poor diet and 22 sedentary lifestyle ${ }^{3}$ coupled with the hormones physiopathology implication such as 23 leptin $^{4}$ and ghrelin 5 .

24 There is a close relationship between waist circumference and cardiovascular risk in 25 obesity $^{6}$, making worried men and women to lose weight using as common strategy to 26 consume less fat but not fewer calories, which indicates they are not using the 27 recommended combination of hypocaloric diet associated with physical activity ${ }^{7,8}$ to 28 achieve permanent changes in lifestyle $\mathrm{e}^{9,10}$ allowing a better obesity control ${ }^{11}$.

29 Some studies references the marital status ${ }^{12}$, level of education ${ }^{13}$ and social classes ${ }^{14}$ 30 with overweight and obesity, but it has been shown that these parameters are not 31 regarded as influential factors in the successful outcome of a treatment ${ }^{15}$.

32 In some cases appetite suppressants that increase anorexigenic neurotransmitters in 33 the central nervous system ${ }^{16}$ as sibutramine ${ }^{17}$ and orlistat have been used, but only 34 maintained if patients responded slimming and keeping the weight achieved without 35 presenting significant side effects ${ }^{18}$, currently these drugs are suspended ${ }^{19}$ and with 36 consumption alerts ${ }^{20}$.

37 Alternative overweight and obesity treatments are very popular and despite being widely 38 used, have not been shown to be safe and effective ${ }^{21}$.

39 In morbid obesity (BMl $\geq 40 \mathrm{~kg} / \mathrm{m}^{2}$ ) sometimes lifestyle changes are not enough ${ }^{22}$ 40 necessitating bariatric surgery to achieve effective weight loss ${ }^{23}$. 
41 In clinical practice it is important to predict nonabdominal, abdominal subcutaneous, and

42 visceral fat in patients by measuring $\mathrm{BMI}$ and waist circumference independently ${ }^{24}$.

43 This study therefore seeks to determine which of the parameters monitored to improve

44 body image and overweight treatment: BMI decrease, weight percentage and waist and

45 hip circumferences loss, could serve for patient motivation.

\section{MATERIAL AND METHODS}

Subjects. A clinical intervention study was conducted among 271 (233 women and 38 men) overweight and obese participants who consulted a nutrition clinic in Barranquilla (Colombia) for the purpose of nutritional assessment. They were subject to a personalized weekly follow-up consultation over the course of 16 weeks. The inclusion criteria were voluntary assistance, patient desire to improve their aesthetic image, excluding those with chronic diseases such as diabetes, kidney failure, etc. since patients came for aesthetic reasons. This study does not consider patients who have done a diet to lose weight in the last month or earlier, as this aspect to analyse the resistance/adherence to current treatment is not necessary. In turn, alcohol and tobacco consumption do not affect actual results. 171(63.1\%) overweight or obese patients according to the WHO classification ${ }^{1}$ continued the study. The sample was formed by patients from 15 to 80 years of age collected over a period of 3 years.

The study was conducted according to Helsinki's rules obtaining all patients informed consent.

Methods. As previous studies ${ }^{25}$, we consider that changes in a nutritional treatment could be seen in 16 continuous weeks. The study included a patient's complete medical

63 record and a weekly WHO's recommended medical-nutritional assessment ${ }^{26}$ by 64 obtaining height, weight, waist and hip circumference data, as well as its own 65 comparison of their initial and final treatment body image through photographs for self66 perception control. We used an eating habits questionnaire similar to Dana-Farber 67 Cancer Institute questionnaire ${ }^{27}$, asking about background and habits at home and work 
68

69

70

71

72

73

74

75

76

77

78

79

80

81

82

83

84

85

86

87

88

89

90

91

92

93

94

95

96

that may relate to patient's health focusing on eating habits. We made weekly low calorie diets WHO-based ${ }^{28}$ according to the questionnaire response.

With the obtained data we calculate the initial and final $\mathrm{BMI}$ according to $\mathrm{WHO}^{1,26}$ criteria, also weight, waist and hip loss percentages.

The data were treated using IBM SPSS Statistics version 22.0 software, checking the normality and comparative nonparametric statistics on data that not showed a normal distribution by Friedman's test. A significance level of $p<0.05$ is considered. This study was approved by SEMI-Servicios Médicos Integrados of Barranquilla, Colombia.

\section{RESULTS}

$63.1 \%$ of patients with successful loss in all the studied variables has been analysed. $36.9 \%$ dropouts were done during the first three visits with no medical reason and no significant relationships regarding sex and $\mathrm{BMI}$, we assume that patients discontinued the treatment because they did not get immediate results in waist loss expected by them. Changes begin to be perceived from the fourth week as shown in Figures. Table 1 shows that in 62 patients from $B M \mid<25$ group, there is a weight loss of $2.6 \%(3.1 \mathrm{SD})$, $5.5 \%(3.3 \mathrm{SD})$ in waist circumference loss and $3.0 \%(2.5 \mathrm{SD})$ in the hip circumference loss. In 67 patients from $25 \leq \mathrm{BMl}<30$ group, there is a weight loss of $3.8 \%(4.1 \mathrm{SD})$, $5.7 \%(4.5 \mathrm{SD})$ in waist circumference loss and $3.7 \%(3.0 \mathrm{SD})$ in the hip circumference loss. 42 patients from $\mathrm{BMI}>30$ group, there is a weight loss of $4.8 \%(3.7 \mathrm{SD}), 7.0 \%(3.6 \mathrm{SD})$ in waist circumference loss and $3.9 \%(2.4 \mathrm{SD})$ in the hip circumference loss. There were statistical significant differences in waist, hip circumference $(\mathrm{HC})$, waist circumference (WC), waist/hip ratio and waist/height ratio shown in table 1 paired test $(p<0.001)$. Friedman's test monitoring for weight (Figure 1), waist (Figure 2) and hip (Figure 3) loss is done every 4 weeks, with significant differences between the three groups $(p<0.001)$. Comparing initial waist/hip circumference ratio and waist/height ratio regarding to final values a clear decrease in the three BMI groups was observed $(p<0.001)($ Table1). When comparing self-perception data through initial and final week patient's treatment photo, they clearly showed satisfaction verifying their waist loss perception (Figure 4. Photograph week 1 and 16). 
98 The concept of body image changes during life affecting individual behaviour ${ }^{29}$, so it

99 cannot be separated from the weight loss. In the present study, we have obtained good

100 results in a high percentage $(63.1 \%)$ of patients who attended the consultation to

101 improve their body image and/or weight loss. These success rates are highly variable in

102 the literature ${ }^{30,31}$ and depends on many factors ${ }^{32}$.

103 It is observed that even patients, who attended the consultation to improve their body 104 image but not overweight ${ }^{1}$, lose BMI, weight, waist and hip, although it is noted that 105 weight stabilizes after 8 treatment weeks. Overweight ${ }^{1}$ group also stabilizes weight at 8 106 weeks; only the obese ${ }^{1}$ group maintains an on-going weight loss until the end of 107 treatment and may indicate the need to extend it for more weeks.

108 Regarding waist loss, in all cases is superior to other examined parameters, keeping this continuously loss for 16 weeks and being higher in the obese ${ }^{1}$ group, not stabilized in either of the three groups, thus is a parameter in which many patients seek superior 111 tracking time, being an appreciated body image index ${ }^{33}$, with a very visual and 112 comparative results with respect to its initial state ${ }^{34}$. Hip losses are lower and 113 temporarily behaving similarly to weight loss. Analysing waist/hip ratio loss, at the end of 11416 treatment weeks the behaviour is similar to waist loss in all BMI groups. Improved 115 nutritional status is evident in the three BMI groups, all indicative body image 116 parameters (waist, hip and waist/height ratio) have significantly improved, and also must 117 notice the waist/height ratio as an important parameter of nutritional improvement status 118 and its relationship to health thus this ratio is effective for predicting relative fatness 119 simplifying the diagnosis of overweight and obesity ${ }^{35}$.

\section{CONCLUSION}

121 After three weeks of continuous treatment patients improved all overweight and obesity 122 parameters indicators; there were not statistical significant differences in hip 
123 circumference (HC) and waist loss (WC) (\%) among the three BMI groups (normal-

124 weight, overweight, and obesity). In contrast, there were statistical significant differences

125 in weight loss (\%) and waist-to-hip ratio. Based on anthropometric outcomes and patient 126 perception of their body image it can be concluded that the waist circumference loss is 127 the parameter that adhere obese patients to the weight loss program.

128

\section{References}

130 1. WHO: Obesity and overweight. Fact sheet $\mathrm{N}^{\circ} 311$. WHO, 2013

131 2. Ogden CL, Carroll MD, Curtin LR, McDowell M A, Tabak CJ, \& Flegal K M: Prevalence of Overweight and Obesity in the United States, 1999-2004. JAMA, 2006; 295(13): 1549-55

3. Centers for Disease Control and Prevention. Report of the National Center for Chronic Disease Prevention and Health Promotion. Physical Activity and Good Nutrition: Essential Elements for Good Health. At-aglance 2010. CDC, 2013

4. Sørensen TI, Echwald S \& Holm JC: Leptin in obesity. BMJ, 1996: 953-4. 
5. Hinney A, Hoch A, Geller F, Schäfer H, Siegfried W, Goldschmidt H, Remschmidt H \& Hebebrand J: Ghrelin Gene: Identification of Missense Variants and a Frameshift Mutation in Extremely Obese Children and Adolescents and Healthy Normal Weight Students. J. Clin. Endocr. Metab, 2013; 87(6): 2716-9

6. Masiá R, Pena A, Marrugat J, Sala J, Vila J, Pavesi M, Covas M, Aubó C \& Elosua R: High prevalence of cardiovascular risk factors in Gerona, Spain, a province with low myocardial infarction incidence. REGICOR Investigators. $J$ Epidemiol Community Health, 1998; 52(11): 707-15

7. Serdula MK, Mokdad AH, Williamson DF, Galuska DA, James MM \& Gregory HW: Prevalence of Attempting Weight Loss and Strategies for Controlling Weight. JAMA, 1999; 282(14): 1353-8

8. Wadden TA: Treatment of obesity by moderate and severe caloric restriction. Results of clinical research trials. Ann Intern Med, 1993; 119: 688-93

9. SIGN: Obesity in Scotland: integrating prevention with weight management. A National Clinical Guideline. Edinburgh: Scottish Intercollegiate Guidelines Network,1996: 1-71

10. NHS: Centre for Reviews and Dissemination. The prevention and treat- ment of obesity. Effective Health Care, 1997; 3: 1-12

11. Benítez Guerrero V, Castillo Torres L, Escalante y García, S, \& Rea Rodríguez C: La obesidad, un problema de salud y su influencia en las relaciones de pareja. Rev Cient Electr Psicol, 2009; (7): 87-96

12. Cano Garcinuño A, Alberola López S, Casares Alonso I, \& Pérez García I: Desigualdades sociales en la prevalencia de sobrepeso y obesidad en adolescentes. An de Pediatr (Barc), 2010; 73 (5): 241-8

13. Mazure R.A, Salgado G, Valencia A, Villarreal P, Cobo B, Peran S \& Culebras J: Ejercicio físico y cirugía bariátrica. Nutr Hosp, 2007; 22(4): 397-401

14. Da Veiga GV, Da Cunha AA, \& Sichieri R: Trends in Overweight Among Adolescents Living in the Poorest and Richest Regions of Brazil. Am J Public Health, 2004; 94(9): 1544-8

15. Kuzmar I, Cortés E, \& Rizo M: Social classes, level of education, marital status, alcohol and tobacco consumption as predictors in a successful treatment of obesity . J Nutr Disor \& Ther, accepted for publication march 20th 2014

16. Yanovski S.Z, \& Yanovski JA: Drug Therapy: Obesity. N Engl J Med, 2002; 346(8): 591-602

17. National Institute for Clinical Excellence: Guidance on the use of sibutramine for the treatment of obesity in adults . London: National Institute for Clinical Excellence, Technology Appraisal Guidance, 2001; 31: 1-12

18. Noël PH \& Pugh JA:. (2002). Clinical review: management of overweight and obese adults. BMJ, 325: 757-61

19. AEMPS: Nota informativa: sibutramina (Reductil囚): suspensión cautelar de comercialización. Comunicación sobre riesgos de medicamentos para profesionales sanitarios, 2010

20. Ministerio de Salud de Chile: Alerta de seguridad: Orlistat. Instituto de Salud Pública de Chile, 2010

21. Allison DB, Fontaine KR, Heshka S, Mentore JL \& Heymsfield SB: Alternative treatments for weight loss: a critical review. Crit Rev Food Sci Nutr, 2001; 41: $1-28$ 
22. National Institute for Clinical Excellence: Guidance on the use of surgery to aid weight reduction for people with morbid obesity. London: National Institute for Clinical Excellence, Technology Appraisal Guidance, 2002; 46: 1-24

23. Morales MJ, Díaz Fernández MJ: Caixa`s, A., \& Cordido , F. Aspectos médicos del tratamiento quirúrgico de la obesidad. Med Clin (Barc), 2011: 1-8

24. Janssen I, Heymsfield SB., Allison D. B, Kotler DP \& Ross R: Body mass index and waist circumference independently contribute to the prediction of nonabdominal, abdominal subcutaneous, and visceral fat. Am J Clin Nutr, 2002; 75: 683-8

25. Kokkinos PF, Narayan P, Colleran JA, Pittaras A, Notargiacomo A, Reda D, \& Vasilios Papademetriou V: Effects of Regular Exercise on Blood Pressure and Left Ventricular Hypertrophy in African-American Men with Severe Hypertension. N Engl J Med, 1995; 333: 1462-7.

26. OMS: El estado físico: uso e interpretación de la antropometría,1995: 308475

27. Dana-Farber Cancer Institute: http://rtips.cancer.gov/rtips/viewProduct.do? viewMode=product\&productld=173387

28. WHO: http://www.who.int/topics/diet/es/

29. Calado M, Lameiras M \& Rodríguez Y: Influencia de la imagen corporal y la autoestima en la experiencia sexual de estudiantes universitarias sin trastornos alimentarios. Int J Clin Health Psychol, 2004; 4 (2): 357-70

30. Hill AJ and Williams J: Psychological health in a non-clinical sample of obese women. Int J Obes, 1998; 22 (6): 578-83

31. Paxton S.J, Schutz HK, Wertheim EH \& Muir SL: Friendship clique and peer influences on body image concerns, dietary restraint, extreme weight-loss behaviors, and binge eating in adolescent girls. J abnorm psych, 1999;108(2): 255-6

32. Paxton SJ, Wertheim EH, Gibbons K, Szmukler GI, Hillier L \& Petrovich, JL: Body image satisfaction, dieting beliefs, and weight loss behaviors in adolescent girls and boys. J Youth Adolesc, 1991; 20 (3): 361-79

33. Casper RC, Halmi KA, Goldberg SC, Eckert ED \& Davis JM: Disturbances in body image estimation as related to other characteristics and outcome in anorexia nervosa. $B J$ Psych, 1979; 134: 60-6

34. Garner DM, Garfinkel PE, Schwartz D \& Thompson M: Cultural expectations of thinness in women. Psych Rep,1980; 47: 483-91

35. Marrodán MD, Martínez-Álvarez JR, González-Montero de Espinosa ML, LópezEjeda N, Cabañas MD, Pacheco JL, Mesa MS, Prado C \& Carmenate MM: Adiposity assessment from waist to height ratio: prediction equations for Spanish infant population. Nutr. Clín.Diet. Hosp, 2011; 31(3): 45-51 


\section{Table 1 (on next page)}

Table 1.

Results of initial and final BMI, weight, waist and hip circumference, and percentage loss in BMI groups at 16 treatment weeks (mean. standard deviation and 95\% confidence interval). 


\begin{tabular}{|c|c|c|c|c|}
\hline $\begin{array}{c}\text { BMI }\left(\mathrm{kg} / \mathrm{m}^{2}\right) \\
\mathrm{n} \\
i \text { BMI mean (SD) }\end{array}$ & $\begin{array}{c}<25 \\
62 \\
23.1(1.3)\end{array}$ & $\begin{array}{c}25 \geq \mathrm{BMI}<30 \\
67 \\
27.5(1.5)\end{array}$ & $\begin{array}{c}>30 \\
42 \\
32.9(3.5)\end{array}$ & p (Kruskal-Wallis) \\
\hline $\begin{array}{c}(\mathrm{Cl} 95 \%) \\
f \mathrm{BMI} \text { mean (SD) }\end{array}$ & $\begin{array}{l}(22.7-23.4) \\
22.5(1.4)\end{array}$ & $\begin{array}{l}(27.2-27.9) \\
26.5(1.7)\end{array}$ & $\begin{array}{l}(31.8-34.0) \\
31.3(3.3)\end{array}$ & 10001 \\
\hline$(\mathrm{Cl} 95 \%)$ & $(22.1-22.8)$ & $(26.1-26.9)$ & $(30.3-32.3)$ & -0.001 \\
\hline Paired test $(p)$ & $<0.001$ & $<0.001$ & $<0.001$ & \\
\hline $\begin{array}{c}i \mathrm{BMI}-f \text { BMI mean (SD) } \\
(\mathrm{Cl} 95 \%)\end{array}$ & $\begin{array}{l}0.6(0.7) \\
(0.4-0.8)\end{array}$ & $\begin{array}{l}1.0(1.1) \\
(0.8-1.3)\end{array}$ & $\begin{array}{l}1.6(1.3) \\
(1.2-2.0)\end{array}$ & $<0.001$ \\
\hline $\begin{array}{l}\text { weight loss \% mean (SD) } \\
\qquad(\mathrm{Cl} 95 \%)\end{array}$ & $\begin{array}{l}2.6(3.1) \\
(1.8-3.3)\end{array}$ & $\begin{array}{l}3.8(4.1) \\
(2.8-4.8)\end{array}$ & $\begin{array}{l}4.8(3.7) \\
(3.6-5.9)\end{array}$ & $<0.05$ \\
\hline $\begin{array}{l}i \text { waist mean (SD) } \\
(\mathrm{Cl} 195 \%)\end{array}$ & $\begin{array}{c}76.3(5.6) \\
(74.9-77.7)\end{array}$ & $\begin{array}{c}86.7(7.3) \\
(85.0-88.5)\end{array}$ & $\begin{array}{l}100.8(11.4) \\
(97.3-104.4)\end{array}$ & $<0.001$ \\
\hline $\begin{array}{l}f \text { waist mean }(\mathrm{SD}) \\
(\mathrm{Cl} 195 \%)\end{array}$ & $\begin{array}{c}72.1(5.4) \\
(70.7-73.5)\end{array}$ & $\begin{array}{c}81.6(6.5) \\
(80.0-83.2)\end{array}$ & $\begin{array}{l}93.7(10.0) \\
(90.5-96.8)\end{array}$ & $<0.001$ \\
\hline $\begin{array}{c}\text { Paired test }(p) \\
\text { waist loss } \% \text { mean (SD) }\end{array}$ & $\begin{array}{l}<0.001 \\
5.5(3.3)\end{array}$ & $\begin{array}{l}<0.001 \\
5.7(4.5)\end{array}$ & $\begin{array}{l}<0.001 \\
7.0(3.6)\end{array}$ & \\
\hline $\begin{array}{c}(\mathrm{Cl} 95 \%) \\
i \text { hip mean (SD) }\end{array}$ & $\begin{array}{l}(4.6-6.3) \\
96.4(5.3)\end{array}$ & $\begin{array}{c}(4.6-6.8) \\
105.8(5.5)\end{array}$ & $\begin{array}{c}(5.9-8.1) \\
115.3(7.3)\end{array}$ & 110 \\
\hline$(\mathrm{Cl} 95 \%)$ & $(95.0-97.7)$ & $(104.4-107.1)$ & $(113.0-117.6)$ & $<0.001$ \\
\hline $\begin{array}{l}f \text { hip mean (SD) } \\
\qquad(\mathrm{Cl} 95 \%)\end{array}$ & $\begin{array}{l}93.5(5.5) \\
(92.1-94.9)\end{array}$ & $\begin{array}{c}101.9(5.9) \\
(100.5-103.4)\end{array}$ & $\begin{array}{c}110.8(7.5) \\
(108.5-113.1)\end{array}$ & $<0.001$ \\
\hline $\begin{array}{c}\text { Paired test }(p) \\
\text { hip loss } \% \text { mean (SD) }\end{array}$ & $\begin{array}{l}<0.001 \\
3.0(2.5)\end{array}$ & $\begin{array}{l}<0.001 \\
3.7(3.0)\end{array}$ & $\begin{array}{l}<0.001 \\
3.9(2.4)\end{array}$ & \\
\hline $\begin{array}{c}(\mathrm{Cl} 95 \%) \\
i \text { waist / } i \text { hip ratio }\end{array}$ & $\begin{array}{c}(2.4-3.6) \\
0.79(0.06)\end{array}$ & $\begin{array}{c}(2.9-4.4) \\
0.82(0.07)\end{array}$ & $\begin{array}{c}(3.2-4.7) \\
0.88(0.09)\end{array}$ & P \\
\hline $\begin{array}{c}\text { mean }(\mathrm{SD})(\mathrm{Cl} 95 \%) \\
f \text { waist } / f \text { hip ratio }\end{array}$ & $\begin{array}{l}(0.78-0.81) \\
0.77(0.06)\end{array}$ & $\begin{array}{l}(0.80-0.84) \\
0.80(0.06)\end{array}$ & $\begin{array}{l}(0.85-0.90) \\
0.85(0.07)\end{array}$ & 0.001 \\
\hline $\begin{array}{c}\text { mean }(\mathrm{SD})(\mathrm{Cl} 95 \%) \\
\text { Paired test }(\mathrm{p}) \\
i \text { waist } / i \text { height ratio }\end{array}$ & $\begin{array}{l}(0.76-0.79) \\
<0.001 \\
0.48(0.04)\end{array}$ & $\begin{array}{l}(0.79-0.82) \\
<0.001 \\
0.53(0.04)\end{array}$ & $\begin{array}{l}(0.82-0.87) \\
<0.001 \\
0.62(0.06)\end{array}$ & . \\
\hline $\begin{array}{c}\text { mean }(\mathrm{SD})(\mathrm{Cl} 195 \%) \\
f \text { waist } / f \text { height ratio }\end{array}$ & $\begin{array}{l}(0.47-0.49) \\
0.45(0.03)\end{array}$ & $\begin{array}{l}(0.52-0.54) \\
0.50(0.03)\end{array}$ & $\begin{array}{l}(0.60-0.64) \\
0.57(0.06)\end{array}$ & -0.001 \\
\hline $\begin{array}{c}\text { mean }(S D)(C 195 \%) \\
\text { Paired test }(p)\end{array}$ & $\begin{array}{l}(0.45-0.46) \\
\quad<0.001\end{array}$ & $\begin{array}{c}(0.49-0.51) \\
<0.001\end{array}$ & $\begin{array}{l}(0.56-0.59) \\
<0.001\end{array}$ & $<0.001$ \\
\hline
\end{tabular}




\section{Figure 1}

\section{Boxplot diagram.}

Weight loss percentage monthly variation in the three studied nutrition groups. Friedman test $p<0.001$

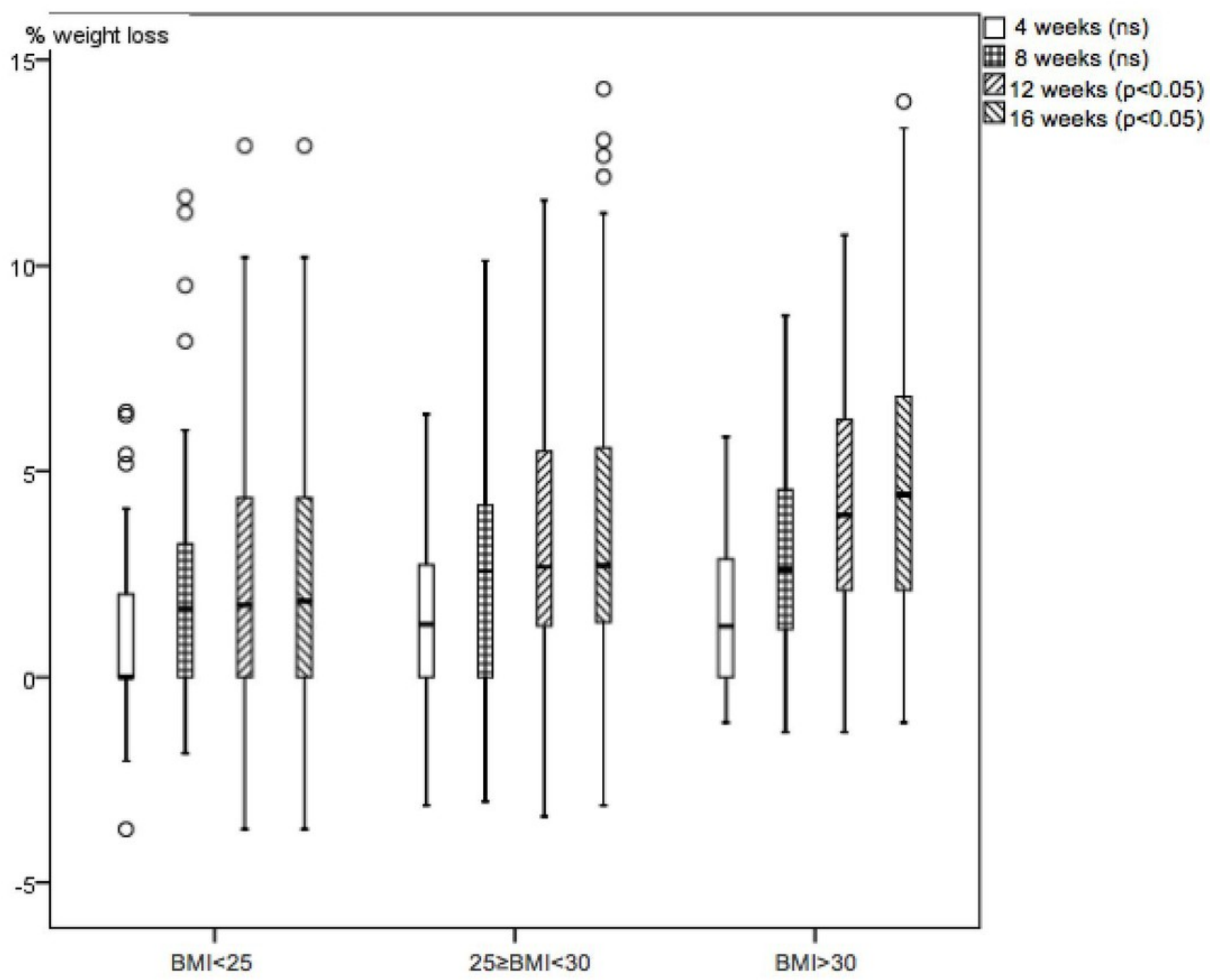




\section{Figure 2}

\section{Boxplot diagram.}

Waist loss percentage monthly variation in the three studied nutrition groups. Friedman test $\mathrm{p}<0.001$

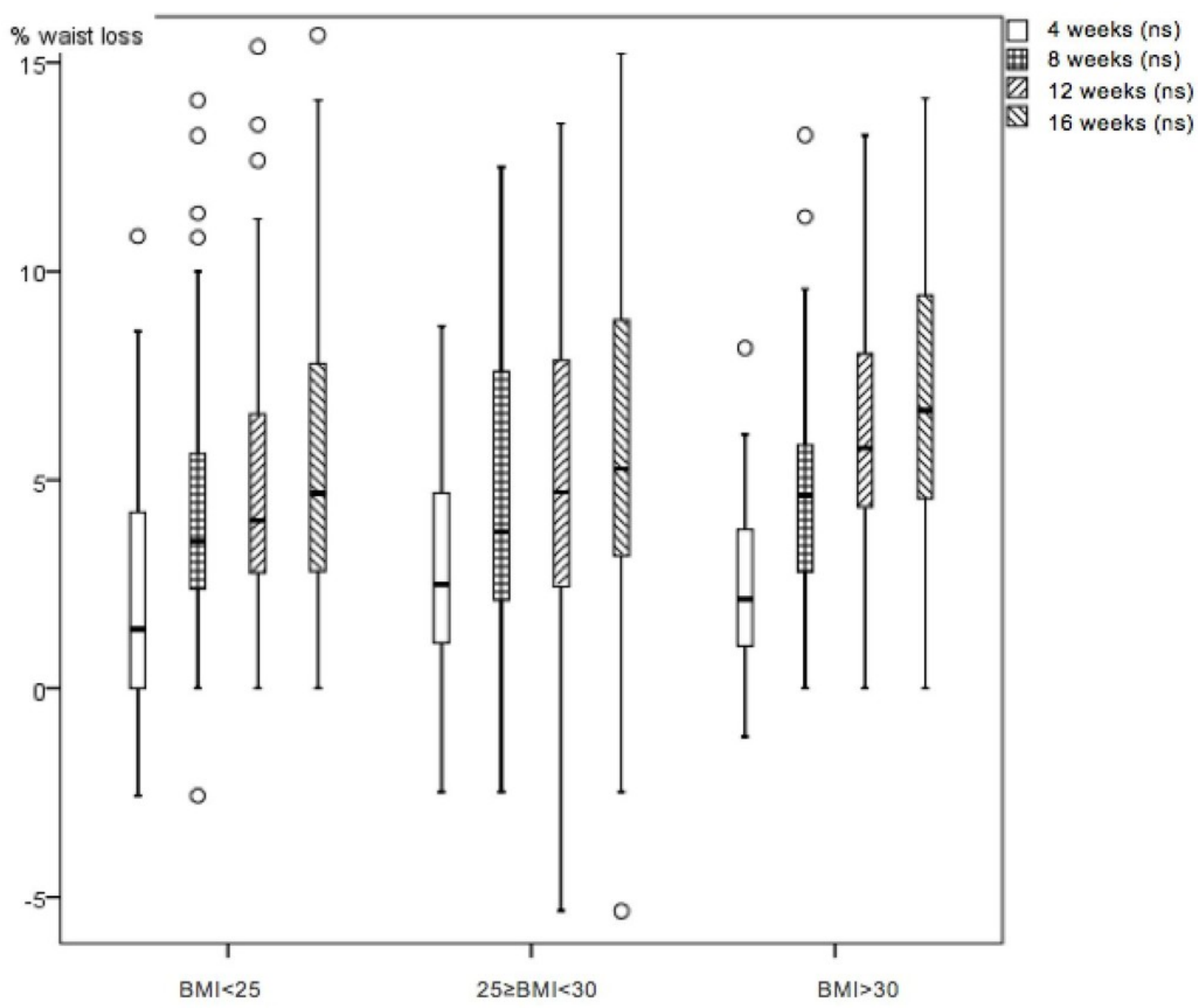




\section{Figure 3}

\section{Boxplot diagram.}

Hip loss percentage monthly variation in the three studied nutrition groups. Friedman test $p<0.001$

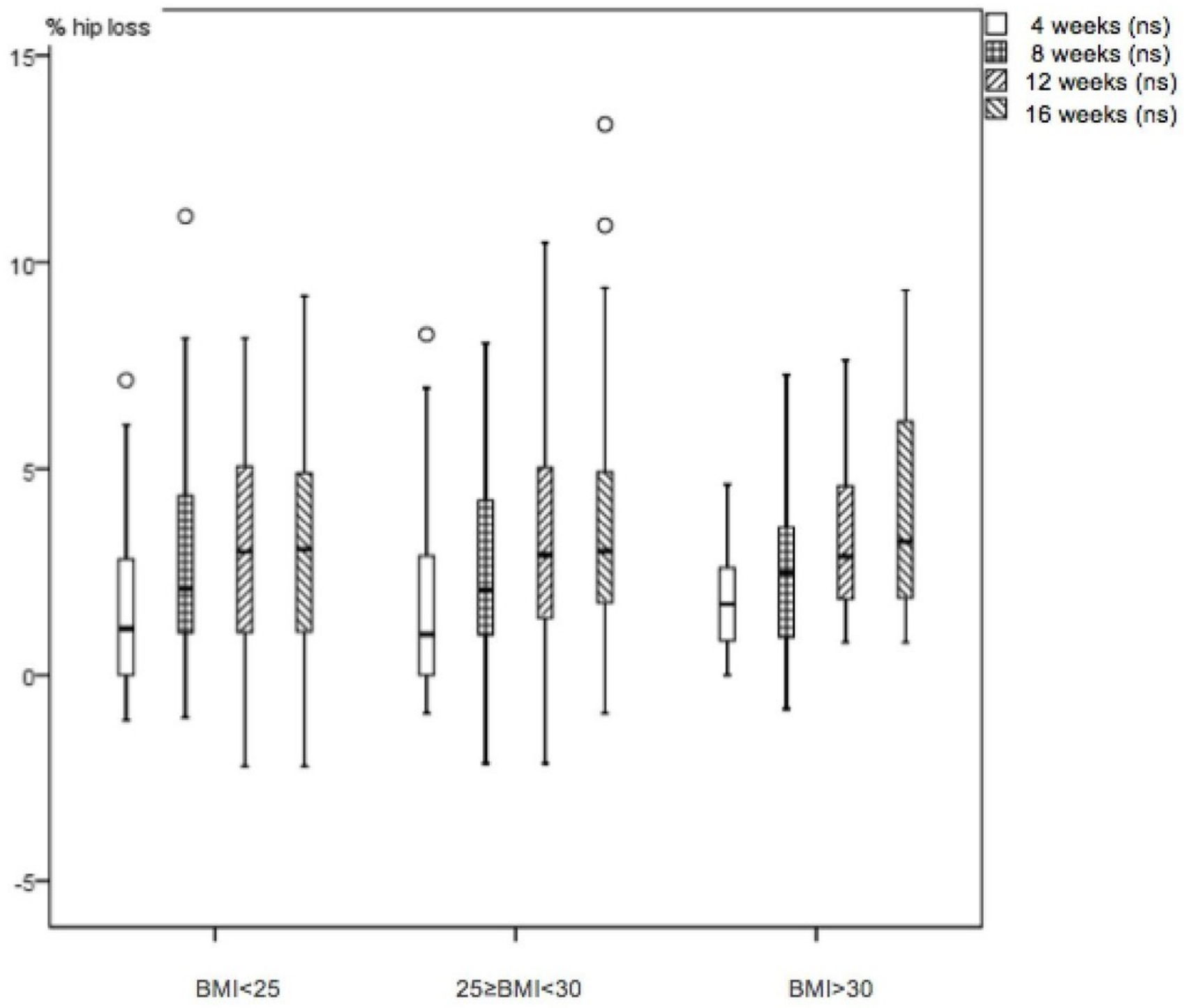




\section{Figure 4}

Treatment photograph.

Patient's photographs at week number 1 and week number 16: helps to motivate the patient, demonstrating body image and self-perception changes. Photo A: week number 1 . Photo B: week number 16.

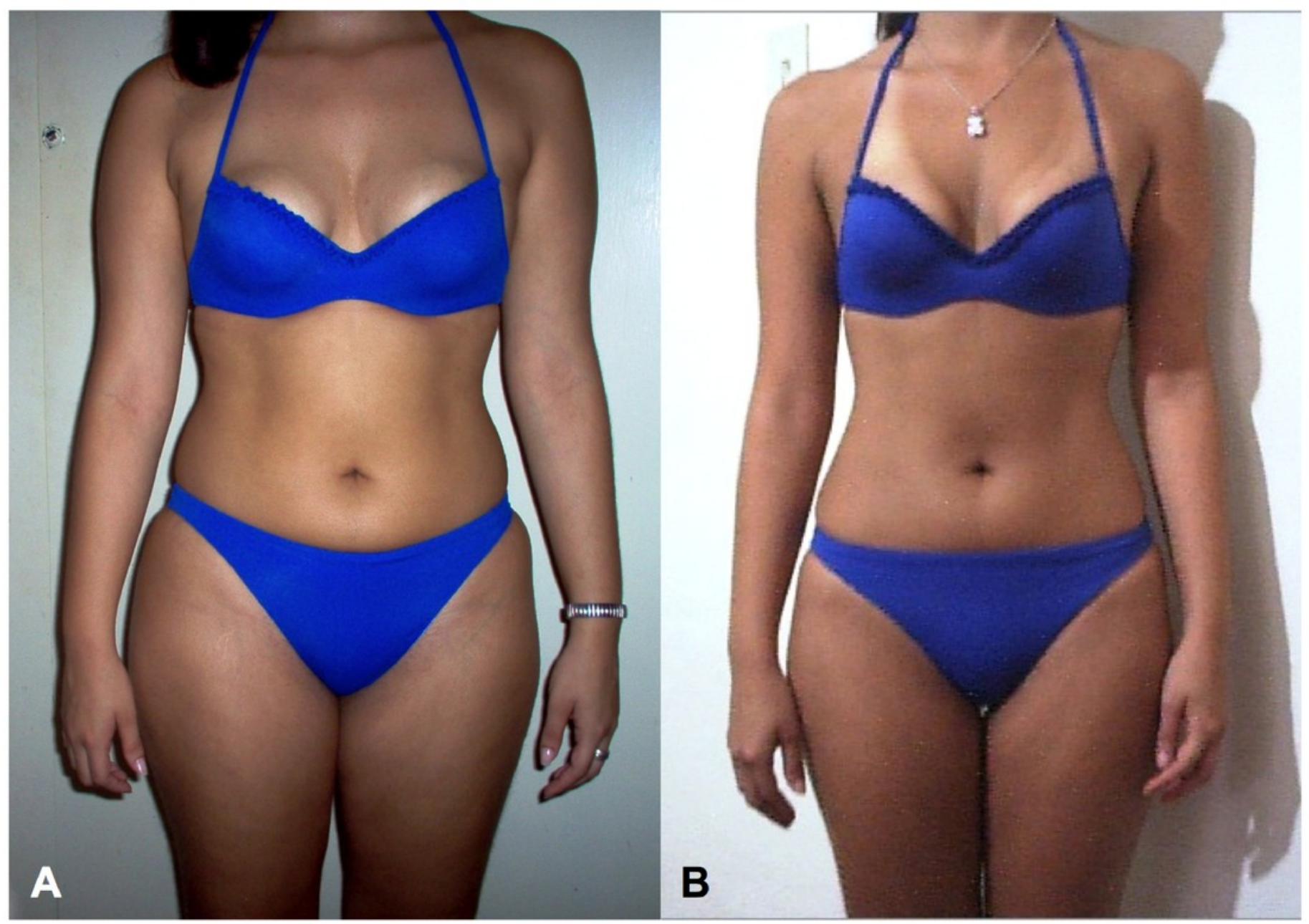

